\title{
HUBUNGAN AGAMA DAN NEGARA DALAM ISLAM
}

\author{
Hani Astika*
}

\section{Abstract}

State and religion relationship is a phenomenon which generating continuous approaches among experts. This is because of variant interpretation toward religion as a part of a state or vice versa.

Kata kunci: Agama, politik, Islam

\section{A. Pendahuluan}

Islam sebagai agama samawi yang komponen dasarnya 'aqidah, syari'ah dan akhlak mempunyai korelasi yang erat dengan politik dalam arti yang luas. Sebagai sumber motivasi masyarakat, Islam berperan penting menumbuhkan sikap dan perilaku sosial politik. Implementasinya kemudian diatur dalam rumusan syari'ah sebagai katalog lengkap dari perintah dan larangan Allah, pembimbing manusia dan pengatur lalu lintas aspek-aspek kehidupan manusia. ${ }^{1}$

Islam dan politik mempunyai titik singgung yang kuat, bila keduanya dipahami sebagai sarana untuk menata hidup secara

'Mahasiswa STAIN Purwokerto Jurusan Syariah Program Studi Muamalah Angkatan 2006. 


\section{Hani Astika}

menyeluruh. Islam tidak hanya dijadikan sebagai "kedok" dan alat "legitimasi" terhadap kekuasaan dan dipahami sebagai sarana perjuangan untuk menduduki struktur kekuasaan. Politik yang dipahami demikian, pada ahirnya akan mengaburkan makna dan menutup kontribusi Islam terhadap dunia politik. Dengan demikian Islam perlu dijadikan sebagai sumber inspirasi kultural dan kerangka paradigmatik dalam pemikiran politik.

Polarisasi pemikiran politik dalam Islam tampaknya lebih disebabkan oleh perbedaan dalam menafsirkan teks-teks normatif agama, disebabkan perbedaan-perbedaan basis sosial budaya yang melingkupinya. Perbedaan itu sangat wajar karena Islam tidak secara eksplisit memberikan suatu formulasi bagi sistem kenegaraan yang baku dan harus diikuti oleh seluruh umat Islam. Perhatian utama Al-Qur'an adalah memberikan landasan etik bagi terbangunnya sistem politik yang didasarkan pada prinsip tegaknya masyarakat yang berkeadilan dan bermoral. ${ }^{2}$

Oleh karena itu, untuk mengkaji pemikiran politik dan sistem ketatanegaraan dalam Islam harus diorientasikan pada upaya menerjemahkan cita-cita politik Islam dengan cara membuat format dan sistem politik yang sesuai dengan etika Al-Qur'an. Pada level inilah perumusan formulasi sistem politik yang sesungguhnya menjadi fokus perdebatan di kalangan pemikir muslim dan zaman klasik sampai pemikir muslim kontemporer. ${ }^{3}$

Mengenai hubungan Islam (juga agama pada umumnya) dan nasionalis tampaknya masih akan terus menjadi masalah. Ada anggapan umum bahwa seseorang tidak mungkin menjadi muslim yang baik sekaligus menjadi warga Indonesia yang baik. Tentu saja situasi itu sangat menyulitkan karena kita dipaksa untuk memilih hanya salah satu dari dua pilihan yang idealnya harus diambil keduanya

\footnotetext{
${ }^{1}$ Ridwan, Paradigma Politik NU (Purwokerto : STAIN Press, 2004), hal. 1

${ }^{2}$ Ibid, hal. 3.

${ }^{3}$ Ibid, hal. 6.
} 
sekaligus. Tapi itulah realitas ideologis-politis kita sejak awal lahirnya negara-bangsa. ${ }^{4}$

Hal ini disebabkan oleh perbedaan pandangan dalam menerjemahkan agama sebagai bagian dari negara atau negara merupakan bagian dari dogma agama. Lebih lanjut ketegangan perdebatan tentang hubungan agama dan negara ini dillhami oleh hubungan yang agak canggung antara Islam sebagai agama (din) dan negara (dawlab).

\section{B. Hubungan Agama dan Negara dalam Sejarahnya}

Salah satu isu yang kontroversial dalam sejarah pemikiran politik Islam adalah mengenai teori khilafah atau imamah. Setelah Nabi Muhammad wafat, masyarakat Islam yang masih baru mengalami kekosongan pemerintahan, dihadapkan pada krisis konstitusional yaitu mengenai bagaimana mekanisme pemilihan kepala negara untuk menggantikan posisi Nabi Muhammad sebagai pemimpin komunitas muslim. ${ }^{5}$

Perdebatan sengit di antara tokoh-tokoh sahabat Nabi mengenai siapa yang berhak dan pantas menjadi pengganti beliau, pada akhirnya melahirkan polarisasi yang mewujud dalam kelompokkelompok atau fraksi-fraksi yang didasarkan pada orientasi politik yang warna dominannya adalah sentimen kesukuan. Secara garis besar paling tidak ada tiga kelompok besar yang muncul pada waktu itu yang secara intens mencoba melakukan mobilisasi massa guna mencari dukungan politik yaitu kelompok Anshar, Muhajirin dan Banu Hasyim. Kelompok Anshar mengajukan Sa'ad Ibn 'Ubadah, kelompok Muhajirin mengajukan Abu Bakar dan Umar bin Khattab, sedangkan kelompok Banu Hasyim mencalonkan Ali bin Abi Thalib. Perdebatan sengit di antara tiga kelompok tersebut terjadi di Thaqifah Bani Sa'ädah.

\footnotetext{
${ }^{4}$ Abdul Rozak, dkk., Buku Suplemen Pendidikan Kewarganegaraan, Jakarta: Prenada Media, 2004), hal. 23.

${ }^{5}$ Ridwan, Paradigma, hal. 52-63.
} 


\section{Hani Astika}

Ketiga kelompok besar tersebut masing-masing Anshar, Muhajirin dan Banu Hasyim mengklaim bahwa kelompoknya yang paling berhak menggantikan posisi Nabi Muhammad dengan argumentasi yang berbeda-beda. Kelompok Anshar merasa paling berhak dengan alasan bahwa merekalah yang selama ini menyambut dan menolong Nabi dalam perkembangan serta kejayaan Islam berkat ada kontribusi yang mereka berikan kepada Nabi dan ummat Islam, ketika mereka ditekan oleh orang-orang kafir Quraisy. Kelompok Muhajirin juga dalam rangka meyakinkan kelompok lain menggunakan legitimasi nash al-Hadits sebagai cara untuk menjustifikasi kepentingannya. Adapun argumentasi yang dibangun kelompok Banu Hasyim dalam mencari dukungan politik bahwa mereka adalah keluarga Nabi, khususnya Ali bin Abi Thalib, oleh karenanya merekalah yang berhak mewarisi posisi Nabi.

Pertemuan di Thaqífah Bani Sa'ädah setelah melakukan perdebatan yang cukup panjang dan melelahkan pada akhirnya memilih Abu Bakar sebagai pengganti Rasulullah (Khalifah Rasulullah). Setelah melewati beberapa ujian dan ancaman, pada akhir pemerintahan yaitu pada tahun ketiga masa jabatannya, ia jatuh sakit dan ia menunjuk Umar bin Khattab untuk menggantikan posisinya. Setelah mendapat persetujuan dari kaum muslimin, Abu Bakar menyuruh Utsman bin Affan untuk menuliskan pengangkatan Umar bin Khattab sebagai khalifah.

Pengangkatan Umar bin Khattab oleh Abi Bakar tampaknya didasari oleh pertimbangan-pertimbangan stabilitas keamanan dan keutuhan kaum muslimin dengan belajar dari sejarah masa lalu, yaitu suasana ketegangan politik ketika pemilihan khalifah Abu Bakar setelah terjadi perdebatan sengit antara sahabat Anshar dan Muhajirin. Dari sini dapat dipahami tindakan Abu Bakar yang mengangkat Umar sebagai khalifah tidak melalui proses pemilihan secara langsung oleh kaum muslimin didasarkan pada trauma sejarah peristiwa Thaqîfah Bani Sa'ädah yang mengancam integritas kaum muslimin. 
Pada masa akhir pemerintahannya, Umar bin Khattab setelah ditikam oleh Abu Lu'lu'ah, Umar bin Khattab membentuk tim formatur (abl al-b\}all wa al-'aqd) yang terdiri dari beberapa sahabat senior, yaitu Ali bin Abi Thalib, Utsman bin Affan, Abdurrahman bin Auf, Sa'ad Ibn Abi Waqash, Zubair bin Awwam, Thalhah bin Ubaidilah dan Abdul bin Umar. Tugas pokok dari tim formatur adalah memilih khalifah yang akan menggantikan posisi Umar bin Khattab. Setelah tim anggota formatur rapat dan melakukan serangkaian konsultasi-konsultasi dengan cara menyerap aspirasi masyarakat, maka Abdurrahman bin Auf sebagai ketua tim formatur menetapkan Utsman bin Affan sebagai pengganti posisi Umar bin Khattab. Secara garis besar pemerintahan Utsman bin Affan dalam kurun waktu dua belas tahun dapat dibedakan dalam dua tahap. Enam tahun pemerintahan Utsman bin Affan berjalan normal di mana administrasi pemerintahan berjalan efektif, perluasan wilayah dilanjutkan dan pembangunan sarana prasarana fisik untuk kepentingan umum tetap berjalan. Tetapi pada enam tahun masa pemerintahan berikutnya pemerintahan Utsman bin Affan mulai tergoncang rakyat di beberapa daerah terutama Kuffah, Basrah, dan Mesir mulai memprotes kebijakan dan tindakannya yang mulai tidak adil.

Protes rakyat atas ketidakpuasan pemerintahan Utsman semakin hari semakin meluas dan berakhir dengan munculnya gerakan demonstrasi secara massif dari berbagai daerah. Akhir dari gelombang demostrasi ditandai dengan terbunuhnya khalifah Utsman akibat ditikam oleh salah seorang demonstran. Di tengah-tengah kekacauan politik para demonstran mendatangi Ali bin Abi Thalib untuk meminta kesediaannya untuk menggantikan posisi Utsman bin Affan sebagai khalifah. Akhirnya Ali bin Abi Thalib bersedia untuk dibaiat menjadi khalifah. Terpilihnya Ali sebagai khalifah di tengah-tengah konflik politik memang melahirkan beberapa persoalan sebagai akibat dari peristiwa terbunuhnya Utsman, yaitu ada beberapa sahabat yang tidak mengakui pemerintahan Ali, khususnya dari bani Umayyah (keluarga Utsman bin Affan) yaitu Gubernur Syam Muawiyah bin Abi Sufyan. Klimaks dari konflik 


\section{Hani Astika}

antara Ali dan Muawiyah ditandai dengan pecahnya perang Siffin yang berakhir dengan peristiwa Tạ̣kim (arbitrase). Dari beberapa peristiwa ini posisi Ali sebagai khalifah semakin lemah karena secara politik kemenangan ada di pihak Muawiyah bin Abi Sufyan.

Dalam sejarah politik Islam, praktek pemerintahan empat khalifah dikenal dengan era "Khulafaur Rasyidin". Era pemerintahan Rasulullah dan Khulafaur Rasyidin inilah sebagai cermin kejayaan Islam dan merupakan model ideal dari sistem ketatanegaraan dalam Islam.

Lain halnya setelah pasca Khulafaur Rasyidin, Muawiyah bin Abi Sufyan mendapatkan kedudukan sebagai khalifah tidak melalui musyawarah lagi atau persetujuan dari tokoh-tokoh masyarakat, tetapi lewat ketajaman pedang dan tipu muslihat. Dari perkembangan kehidupan kenegaraan pada masa itu dan masa sesudahnya kiranya tidak banyak hal yang perlu mendapatkan perhatian kita, karena tidak mempunyai relevansi dengan maksud kajian ulang yakni mencari pola baku kehidupan kenegaraan yang Islami, oleh karena baik selama kekuasaan Muawiyah maupun Dinasti Abbasiyah hampir sama sekali tidak pernah terjadi perubahan-perubahan yang diprakarsai atau dilakukan para penguasa yang bersifat konsepsional dan yang mencerminkan pengembangan atau aplikasi ajaran Islam tentang tata negara. ${ }^{6}$

\section{Konsep Relasi Agama dan Negara dalam Islam}

Dalam Islam, hubungan agama dan negara menjadi perdebatan yang cukup panjang di antara para pakar Islam hingga kini. Dalam lintasan historis Islam, hubungan agama dan negara dan sistem politik menunjukkan fakta yang sangat beragam. Banyak para ulama tradisional yang berargumentasi bahwa Islam merupakan sistem kepercayaan di mana agama memiliki hubungan erat dengan politik. Islam memberikan pandangan dunia dan makna hidup bagi manusia termasuk bidang politik. ${ }^{?}$

${ }^{6}$ Munawar Syadzali, Islam dan Tata Negara, (Jakarta: UI Press, 1993), hal. 34.

${ }^{7}$ Dede Rosyada, dkk., Demokrasi, Hak Asasi, Manusia dan Masyarakat Madani, (Jakarta: Tim ICCE UIN Jkarta, 2003), hal. 61. 
Dari sudut pandang ini maka pada dasarnya dalam Islam tidak ada pemisahan antara agama dan politik (dawlab). Argumentasi ini sering dikaitkan dengan posisi Nabi Muhammad ketika berada di Madinah yang membangun sistem pemerintahan dalam sebuah negara kota. Di Madinah Rasulullah berperan sebagai kepala pemerintahan sekaligus sebagai kepala agama. Menyikapi hal ini, Ibnu Taimiyah mengatakan bahwa posisi Nabi saat itu adalah sebagai Rasul yang bertugas menyampaikan ajaran (al-kitäb) bukan sebagai penguasa. Kalaupun ada pemerintahan, itu hanyalah sebuah alat untuk menyampaikan agama dan kekuasaan bukanlah agama. Dengan kata lain, politik atau negara hanyalah sebagai alat bagi agama bukan suatu eksistensi dari agama. Pendapat Ibnu Taimiyah ini dipertegas dengan ayat Al-Qur'an yang artinya, "Sesungguhnya Kami telah mengutus Rasul-rasul Kami yang disertai keterangan-keterangan dan Kami turunkan beri padanya ada kekuatan yang hebat dan manfaat-manfaat bagi manusia dan Allab mengetabui siapa yang menolong-Nya dan menolong Rasul-Nya yang ghaib (dari padanya)." (QS. 57: 25).

Dari ayat di atas Ibnu Taimiyah mengatakan bahwa agama yang benar, wajib memiliki buku petunjuk dan pedang penolong. Hal ini dimaksudkan bahwa kekuasaan politik yang disimbolkan dengan pedang menjadi sesuatu yang mutlak bagi agama, tetapi kekuasaan itu bukanlah agama itu sendiri. Syafi'i Ma'arif menegaskan bahwa istilah dawiah yang berarti negara tidak dijumpai dalam Al-Qur'an. Istilah dawlah memang ada di dalam Al-Qur'an (QS. 57: 25) tetapi bukan bermakna negara. Istilah tersebut dipakai secara figuratif untuk melukiskan peredaran atau pergantian tangan dari kekayaan. ${ }^{8}$

Fazlur Rahman, kendatipun tidak menyatakan secara gamblang pendapatnya mengenai konsep Islam mengenai negara nampaknya lebih cenderung berpendapat bahwa Islam tidak memerintahkan dan juga tidak mengajarkan secara jelas mengenai sistem ketatanegaraan tetapi mengakui pendapatnya sejumlah tata nilai dan etika dalam

\footnotetext{
${ }^{8}$ A. Syafi'i Ma'arif, Islam dan masalab Kenegaraan, (Jakarta: LP3ES, 1996), hal. 14.
} 
Al-Qur'an. Kendatipun Nabi Muhammad tidak pernah menyatakan dirinya sebagai pemimpin negara tetapi dia telah menjadikan negara sebagai alat bagi agama Islam untuk menyebarkan dan mengembangkan agama. ${ }^{9}$

Sama halnya dengan pendapat yang dikemukakan oleh Muhammad Husein Haikal. Menurutnya prinsip-prinsip dasar kehidupan kemasyarakatan yang diberikan oleh Al-Qur'an dan AsSunnah tidak ada yang langsung berkaitan dengan ketatanegaraan. Lebih lanjut ia mengatakan bahwa dalam Islam tidak terdapat suatu sistem pemerintahan yang baku. Umat Islam bebas menganut sistem pemerintahan yang bagaimanapun asalkan sistem tersebut menjamin persamaan antara para warga negaranya, baik hak maupun kewajiban dan juga di muka hukum serta pengelolaan urusan negara diselenggarakan atas syara atau musyawarah dengan berpegang kepada tata nilai moral dan etika yang diajarkan Islam. ${ }^{10}$

Abdurrahman Wahid, juga memberikan porsi pemikiran yang cukup signifikan tentang pergaulan negara dan agama, serta berusaha memberikan alternatif-alternatif dalam dua pertentangan tersebut. Menurutnya, pemikiran negara dalam pandangan Islam pada dasarnya dapat dibagi ke dalam dua jenis pemikiran, yaitu pemikitan idealistik dan pemikiran realistik. Pemikiran idealistik berusaha secara sadar merumuskan sebuah kerangka negara yang sepenuhnya berdasarkan wawasan Islam. Dalam pandangan ini, Islam merupakan sebuah konsep kenegaraan yang harus diwujudkan secara penuh dalam sebuah bangunan masyarakat yang seratus persen Islam. Sedangkan pemikiran realistik tidak begitu tergoda oleh bangunan utopis dari sebuah negara ideal menurut wawasan Islami, tetapi lebih tertarik pada pemecahan masalah bagaimana perkembangan historis dapat ditampung dalam Islam tentang negara.

Dalam lintasan sejarah dan opini para teoritisi politik Islam ditemukan beberapa pendapat yang berkenaan dengan konsep

${ }^{9}$ M. Hasbi Amirudin, Konsep Negara Islam Menurut Fazlur Rabman, (Yogyakarta: UII Press, 2000), hal. 80.

${ }^{10}$ Munawar Syadzali, Islam dan Tata Negara, (Jakarta: UI Press, 1993), hal. 183. 
hubungan agama dan negara, antara lain dapat diragukan ke dalam (tiga) paradigma, yakni integralistik, simbiotik, dan sekularistik. ${ }^{11}$

\section{Paradigma Integralistik}

Paradigma integralistik merupakan paham dan konsep hubungan agama dan negara yang menganggap bahwa agama dan negara merupakan suatu kesatuan yang tidak dapat dipisahkan. Keduanya merupakan dua lembaga yang menyatu (integrated). Ini juga memberikan pengertian bahwa negara merupakan suatu lembaga politik dan sekaligus lembaga agama. Konsep ini menegaskan kembali bahwa Islam tidak mengenal pemisahan antara agama dan politik atau negara.

Paradigma ini kemudian melahirkan konsep tentang agama negara, yang berarti bahwa kehidupan kenegaraan diatur dengan menggunakan hukum dan prinsip keagamaan. Dari sinilah kemudian paradigma integralistik dikenal juga dengan paham Islam din wa dawlah, yang sumber hukum positifnya adalah hukum agama. Paradigma integralistik ini antara lain dianut oleh kelompok Islam Syi'ah. Hanya saja Syi'ah tidak menggunakan term dawlah tetapi term imamah.

\section{Paradigma Simbiotik}

Menurut konsep ini, hubungan agama dan negara dipahami saling membutuhkan dan bersifat timbal balik. Dalam konteks ini, agama membutuhkan negara sebagai instrumen dalam melestarikan dan mengembangkan agama. Begitu juga sebaliknya, negara juga memerlukan agama, karena agama juga membantu negara dalam pembinaan moral, etika dan spiritualitas.

Dalam konteks paradugma simbiotik, Ibnu Taimiyah mengatakan bahwa adanya kekuasaan yang mengatur kehidupan manusia merupakan kewajiban agama yang paling besar, karena tanpa kekuasaan negara, maka agama tidak bisa berdiri tegak.

${ }^{11}$ Dede Rosyada, dkk., Demokrasi..., hal. 62-64.

Al Manāhij, Vol. 2 No. 1 Januari - Juni 2008 


\section{Hani Astika}

Pendapat Ibnu Taimiyah tersebut melegitimasi bahwa antara agama dan negara merupakan dua entitas yang berbeda, tetapi saling membutuhkan. Oleh karenanya, konstitusi yang berlaku dalam paradigma ini tidak saja berasal dari adanya social contact, tetapi bisa saja diwarnai oleh hukum negara.

\section{Paradigma Sekularistik}

Paradigma sekularistik beranggapan bahwa ada pemisahan (disparitas) antara negara dan agama. Negara dan agama merupakan dua bentuk yang berbeda dan satu sama lain memiliki garapan bidangnya masing-masing, sehingga keberadaannya harus dipisahkan dan tidak boleh satu sama lain melakukan intervensi.

Berdasar pada pemahaman yang dikotomis ini, maka hukum positif yang berlaku adalah hukum yang betul-betul berasal dari kesepakatan manusia melalui social contact dan tidak ada kaitannya dengan hukum agama. Konsep sekularistik ini bisa dilihat dari pendapat Ali Abdul Raziq yang menyatakan bahwa dalam sejarah kenabian Rasulullah pun tidak ditemukan keinginan Nabi Muhammad untuk mendirikan agama. Rasulullah hanya penyampai risalah kepada manusia dan mendakwahkan ajaran agama kepada manusia.

\section{Hubungan Islam dan Negara di Indonesia}

Masalah hubungan Islam dan negara di Indonesia merupakan persoalan yang menarik untuk dibahas, karena tidak saja Indonesia merupakan negara yang mayoritas warga negaranya beragama Islam, tetapi karena kompleksnya persoalan yang muncul. Untuk itu agar kita mendapat informasi yang lebih mendetail mengenai hubungan Islam dan negara dalam lintasan Indonesia, lebih baiklah kita runtut ke belakang mengenai sejarah perdebatan antara Islam dan politik yang terjadi di Indonesia.

Setelah Jepang menyerah kepada sekutu pada tanggal 15 Agustus 1945, pada tanggal 17 Agustus 1945 Indonesia menyatakan kemerdekaannya di bawah pimpinan Soekarno dan Moh. Hatta, dua tokoh bangsa yang sejak tahun 1920-an bekerja keras untuk 
kemerdekaan tanah air. Untuk mengenal antusiasme politik umat pada hari-hari kemerdekaan, dipandang perlu untuk mengikuti perkembangan politik nasional pada sekitar 3 bulan sebelum deklarasi kemerdekaan itu. Pembicaraan tentang periode singkat tapi penting ini akan membantu kita untuk mendudukkan politik umat Islam dan peranan yang dimainkannya selama bulan-bulan menjelang kemerdekaan itu. $^{12}$

Agar kita memiliki dan mendapat gambaran yang jelas tentang perdebatan pandangan politik selama bulan-bulan menjelang kemerdekaan, perdebatan sengit dalam BPUPKI (Badan Penyelidik Usaha-usaha Persiapan Kemerdekaan Indonesia) antara wali-wali umat Islam dan pemimpin-pemimpin nasional, perlu dikaji lebih teliti isu yang paling krusial dalam perdebatan-perdebatan itu ialah tentang ideologi negara Indonesia yang bakal lahir itu. Isu ini punya dampak politik ideologis yang dalam dan panjang dalam perjalanan sejarah modern Indonesia.

Dalam majelis konstituante, pada mulanya ada tiga rancangan (draft) tentang dasar negara yang diajukan oleh tiga fraksi. Ketiga rancangan itu adalah: Pancasila, Islam dan Sosial-Ekonomi. Dan yang terakhir tidak diajukan karena hanya didukung oleh kelompok kecil. Soekarno dan Yamin mengajukan Lima Prinsip Dasar yang kemudian dikenal dengan Pancasila. Sedangkan dari golongan Islam yaitu Ki Bagus Hadi Kusumo seorang tokoh Muhammadiyah, dengan mengajukan Islam sebagai dasar negara. Usul Ki Bagus ini merupakan anti-tesis terhadap usul Soekarno-Yamin. Dengan munculnya dua usul yang berbeda itu, maka bermulalah pergumulan pertama antara Pancasila dan Islam dalam sidang BPUPKI. ${ }^{13}$

Dari situ jelas bahwa soal dielematik belum terpecahkan. Pada satu pihak, kelompok pendukung dasar Islam dalam BPUPKI ingin melaksanakan seluruh isi syariah yang telah tersedia tanpa suatu reformulasi tuntas dengan menghubungkannya dengan ajaran etik

${ }^{12}$ A. Syafi'i Ma'arif, Islam dan Politik di Indonesia, (Yogyakarta: IAIN Sunan Kalijaga Press, 1988), hal. 23.

${ }^{13}$ Ibid, hal. 27. 
Al-Qur'an sebagaimana yang dipahami pada waktu ini. Formulasi sistematik ini diperlukan agar hukum-hukum Islam berjaya menghadapi persoalan modern yang dihadapi manusia. Di pihak lain, kelompok nasionalis sekuler tampaknya hanyalah ingin mengurung Islam dalam sebuah sangkar "urusan pribadi" seorang muslim. Isu tentang dasar negara ini telah memaksa para pendiri Republik Indonesia untuk menjalani masa-masa yang sulit dalam sejarah modern Indonesia. Tetapi akhirnya, sebuah kompromi politik dalam bentuk piagam dasar pada tanggal 22 Juni 1945 dapat dicapai. Piagam Jakarta adalah hasil kerja sebuah pantia kecil dalam BPUPKI yang diketuai Soekarno, dan ditandatangani oleh sembilan anggota terkemuka yaitu: Soekarno, Moh. Hatta, AA. Maramis, Abikusno T., Abdul Kahar Muzakir, Agus Salim, Ahmad Subarjo, Wachid Hasyim dan Muhammad Yamin.

Piagam Jakarta sebenarnya adalah sebuah preambule bagi kosntitusi yang diajukan dalam sidang BPUPKI. Di dalamnya, Pancasila sebagai dasar negara telah disepakati, tapi sila pertama, yaitu sila Ketuhanan diikuti oleh klausul ...dengan kewajiban menjalankan syariat Islam bagi pemeluk-pemeluknya. Bagi umat Islam, anak kalimat ini menjadi sangat penting, sebab dengan itu tugas pelaskanaan syariat Islam secara konstitusional terbuka pada waktu yang akan datang. Inilah salah satu alasan mengapa wakil-wakil umat Islam dalam BPUPKI dapat berkompromi dengan kaum nasionalis. Sisi lain yang menarik dari sini ialah bahwa anggota panitia kecil, kecuali Maramis yang Kristen semuanya beragama Islam.

Soekarno sebagai ketua panitia kecil mengharapkan agar semua pihak, khususnya wakil-wakil Kristen, menerima hasil kompromi di atas, sekalipun hal itu berarti pengorbanan yang besar bagi mereka yaitu pengorbanan yang tidak boleh tidak bagi kemerdekaan Indonesia. Sekalipun wakil-wakil Kristen menerima dengan perasaan berat himbauan Soekarno itu, namun perumusan konstitusi 1945 pada akhirnya diterima dengan aklamasi pada tanggal 16 Juni $1945 .{ }^{14}$

${ }^{14}$ Ibid, hal. 108. 
Namun demikian, sebelum proklamasi kemerdekaan Indonesia masih ada duri dalam daging Pancasila dan UUD 1945 yang masih tetap dirasakan sebagai sesuatu yang mengganggu sebagian anggota BPUPKI, terutama kelompok agama minoritas. Duri tersebut tidak lain adalah ...dengan kewajiban menjalankan syariat Islam bagi pemelukpemeluknya... sebagaimana telah disebut terdahulu. Setelah melewati saat-saat yang cukup kritis, pada tanggal 18 Agustus 1945, wakilwakil umat Islam akhirnya menyetujui usul penghapusan anak kalimat tersebut dari Pancasila dan batang tubuh UUD 1945. Akan tetapi, sila pertama Pancasila yaitu sila Ketuhanan mendapat tambahan atribut yang sangat kunci, hingga menjadi "Ketuhanan Yang Maha Esa". Modifikasi sila pertama ini dipandang sangat berarti, sebab dengan jalan demikian wakil-wakil umat Islam tidak akan keberatan dengan formula baru itu. Akan tetapi, perubahan di atas dipandang oleh sebagian orang sebagai kekalahan politik wakil-wakil umat Islam. Tetapi pada tahun 1978, Alamsyah Ratu Perwiranegara (Menteri Agama waktu itu) menafsirkan peristiwa tertanggal 18 Agustus itu sebagai hadiah umat Islam kepada bangsa dan kemerdekaan Indonesia, demi menjaga persatuan. ${ }^{15}$

Dalam mengkaji hubungan agama dan negara di Indonesia, secara umum dapat digolongkan ke dalam 2 bagian, yakni hubungan yang bersifat antagonistik dan hubungan yang bersifat akomodatif. Hubungan antagonistik merupakan sifat hubungan yang mencirikan adanya ketegangan antara negara dengan Islam sebagai sebuah agama. Sedangkan paham akomodatif lebih dipahami sebagai sifat hubungan di mana negara dan agama satu sama lain saling mengisi bahkan ada kecenderungan memiliki kesamaan untuk mengurangi konflik. ${ }^{16}$

1. Hubungan Agama dan Negara yang Bersifat Antagonistik

Eksistensi Islam politik (political Islam) pada masa kemerdekaan dan sampai pada pasca revolusi pernah dianggap sebagai pesaing

${ }^{15}$ Ibid, hal. 108.

${ }^{16}$ M. Imam Aziz, Agama, Demokrasi dan Keadilan Jakarta: Gramedia Pustaka Utama, 1993), hal. 105. 


\section{Hani Astika}

kekuasaan yang dapat mengusik basis kebangsaan negara. Persepsi tersebut, membawa implikasi terhadap keinginan negara untuk berusaha menghalangi dan melakukan domestikasi terhadap gerak ideologis Islam. Lebih dari itu, bahkan politik Islam sering dicurigai sebagai anti ideologi negara pancasila. ${ }^{17}$

Bahtiar Effendi mengatakan bahwa di Indonesia, akar antagonistik hubungan politik antara Islam dua negara tak dapat dilepaskan dari konteks kecenderungan pemahaman keagamaan yang berbeda. Awal hubungan yang antagonistik ini dapat ditelusuri dari masa pergerakan kebangsaan, ketika elit politik nasional terlibat dalam perdebatan tentang kedudukan Islam di alam Indonesia merdeka.

Setelah pemerintahan Orde Baru memantapkan kekuasaannya, terjadi kontrol yang berlebihan yang diterapkan oleh Orde Baru terhadap kekuatan politik Islam, terutama pada kelompok radikal yang dikhawatirkan semakin militan dan menandingi eksistensi negara.

Realitas empirik inilah yang kemudian menjelaskan bahwa hubungan agama dan negara betul-betul mencurigai Islam sebagai kekuatan yang potensial dalam menandingi eksistensi negara. Di sisi lain, umat Islam sendiri pada masa itu memiliki ghirah yang tinggi untuk mewujudkan Islam sebagai sumber ideologi dalam menjalankan pemerintahan.

\section{Hubungan Agama dan Negara yang Bersifat Akomodatif}

Gejala menurunnya ketegangan hubungan antara Islam dan negara mulai terlihat pada pertengahan tahun 1980-an. Hal ini ditandai dengan semakin besarnya peluang umat Islam dengan mengembangkan wacana politik serta munculnya kebijakankebijakan yang dianggap positif bagi umat Islam.

Kecenderungan akomodasi negara terhadap Islam juga menurut Affan Gaffar ditengarai dengan adanya kebijakan

${ }^{17}$ Bahtiar Effendi, Teologi Baru Politik Islam: Pertautan Agama, Negara dan Demokrasi, (Yogyakarta: Galang Press, 2001), hal. 4. 
pemerintah dalam bidang pendidikan dan keagamaan serta kondisi dan kecenderungan politik umat Islam sendiri. ${ }^{18}$ Pemerintah menyadari bahwa umat Islam merupakan kekuatan politik yang potensial, yang oleh karenanya negara lebih memilih akomodasi terhadap Islam, karena jika negara menempatkan Islam sebagai outsider negara, maka konflik akan sulit dihindari yang pada akhirnya akan membawa imbas terhadap proses pemeliharaan negara kesatuan Republik Indonesia.

Menurut Thaba, munculnya sikap akomodatif negara terhadap Islam lebih disebabkan oleh adanya kecenderungan bahwa umat Islam Indonesia dinilai telah semakin memahami kebijakan negara terutama dalam konteks pemberlakuan dan penerimaan asas tunggal Pancasila. ${ }^{19}$ Selain itu, munculnya kebijakan negara terhadap Islam juga menjadi bagian yang penting dalam memahami hubungan agama dan negara di masa awal 1980-an, misalnya pengetahan RUU Pendidikan Nasional, pengesahan RUU Peradilan Agama, munculnya KMI serta munculnya Yayasan Amal Bhakti Muslim Pancasila yang secara massif membangun ratusan masjid di hampir seluruh Indonesia.

\section{E. Kesimpulan}

Tidak pernah selesainya perdebatan mengenai hubungan antara agama dan negara seolah menjadi persoalan tersebut menjadi persoalan abadi, tidak hanya dalam konteks ke-Indonesia-an, melainkan dunia pada umumnya. Dalam lintasan historis Islam, hubungan agama dan negara dan sistem politik menunjukkan fakta yang sangat beragam. Banyak para ulama tradisional yang berargumentasi bahwa Islam merupakan sistem kepercayaan di mana agama memiliki hubungan erat dengan politik. Islam memberikan pandangan dunia dan makna hidup bagi manusia termasuk bidang politik. Dari sudut pandang ini maka pada dasarnya dalam Islam

\footnotetext{
${ }^{18}$ M. Imam Aziz, Agama..., hal. 105.

${ }^{19}$ Abdul Aziz Thaba, Islam dan Negara dalam Politik Orde Baru, Jakarta: Gema Insani Press, 1996), hal. 15.
} 
tidak ada pemisahan antara agama (din) dan politik (dawlab). Karena dalam perspektif Al-Qur'an, institusi kekuasaan yang bersama negara diperlukan sebagai instrumen yang efektif untuk merealisasikan ajaran-ajaran dalam konteks sejarah. Kemudian dalam menghadapi kenyataan puluhan negara nasional di dunia Islam, pembentukan suatu liga bangsa-bangsa dengan struktur organisasi yang longgar mungkin dapat dipertimbangkan dalam rangka menerjemahkan prinsip persaudaraan umat pada kancah Internasional.

\section{DAFTAR PUSTAKA}

Amirudin, M. Hasbi. Konsep Negara Islam Menurut Fazlur Rabman. Yogyakarta: UII Press, 2000.

Aziz, M. Imam. Agama, Demokrasi, dan Keadilan. Jakarta: Gramedia Pustaka Utama, 1993.

Effendi, Bachtiar. Teologi Baru Politik Islam: Pertautan Agama, Negara, dan Demokrasi. Yogyakarta: Galang Press, 2001.

Ma'arif, A. Syafi'i. Islam dan Politik di Indonesia. Yogyakarta: IAIN Sunan Kalijaga Press, 1988.

. Islam dan masalab Kenegaraan. Jakarta: LP3ES, 1996.

Ridwan. Paradigma Politik NU. Purwokerto: STAIN Press, 2004.

Rozak, Abdul; dkk. Buku Suplemen Pendidikan Kewarganegaraan. Jakarta: Prenada Media, 2004.

Rosyada, Dede; dkk. Demokrasi, Hak Asasi Manusia, dan Masyarakat Madani. Jakarta: Tim ICCE UIN Jakarta, 2003.

Syadzali, Munawar. Islam dan Tata Negara. Jakarta: UI Press, 1993. Thaba, Abdul Aziz. Islam dan Negara dalam Politik Orde Baru. Jakarta: Gema Insani Press, 1996. 